\title{
Effect of Physical Training on Glucose Tolerance and on Glucose Metabolism of Skeletal Muscle in Anaesthetized Normal Rats
}

\author{
M. Berger, F. W. Kemmer, K. Becker, L. Herberg, M. Schwenen, A. Gjinavci, and P. Berchtold \\ Diabetes Research Institute, Institute of Physiological Chemistry, Department of Medicine, University of Düsseldorf, FRG, \\ and Institut de Biochemie Clinique, University of Geneva, Switzerland
}

\begin{abstract}
Summary. The effect of physical training on glucose tolerance in vivo and skeletal muscle glucose metabolism in vitro was investigated in normal rats. Treadmill running for 10 days up to $240 \mathrm{~min} /$ day led to a decrease of basal and glucose-stimulated plasma insulin levels without major alterations of the IV glucose tolerance $(1 \mathrm{~g} / \mathrm{kg}$ body weight). Swim training of two weeks' duration, i. e. exercise up to $2 \times 75 \mathrm{~min} /$ day, which did not induce significant changes in body composition, skeletal muscle glycogen levels or citrate synthase activity, resulted in a significant improvement of IV glucose tolerance and substantial reductions of basal and glucose-stimulated plasma insulin levels. Associated with this apparent improvement of insulin sensitivity in vivo, significant increases of the insulin-stimulated glucose uptake $(+55 \%)$ and lactate oxidation $(+78 \%)$ in vitro were found on perfusion of the isolated hindquarter of swim-trained animals. It is suggested that mild physical training can improve glucose tolerance and insulin sensitivity in normal rats, at least in part, due to an increase of insulin sensitivity of skeletal muscle glucose metabolism.
\end{abstract}

Key words: Physical training, glucose tolerance, skeletal muscle glucose metabolism, insulin sensitivity.

Although physical activity is generally recommended for patients with diabetes mellitus $[1,2,3]$ a positive effect of training on glucose tolerance has so far not been documented. While it is well known that immobilisation leads to an impairment of glucose tolerance in man $[4,5]$ and in animals [5], even after long-term physical training the glucose tolerance remained unchanged [6-12]. On the other hand, Björntorp and his colleagues have demonstrated in several different groups of patients $[9,10,11,12]$ that prolonged physical training was associated with a marked decrease in basal, as well as glucose-stimulated circulating insulin levels. Similarly, Lohman et al. [13] have recently shown reduced basal and glucose-stimulated circulating insulin levels in athletes. Since in these studies, glucose tolerance remained essentially unchanged, the authors have postulated increased peripheral insulin sensitivity induced by physical training [12], a likely site being the skeletal muscle mass. The aim of this study was to analyse the effect of physical training of different types on intravenous glucose tolerance in normal rats and to investigate the insulin sensitivity of perfused skeletal muscle in trained and untrained rats.

\section{Methods}

\section{Animals}

Female Wistar rats (bred from the stock of the Institut de Biochimie Clinique, Geneva) or female Osborne-Mendel rats (bred from the stock of the Diabetes Research Institute, Düsseldorf), were kept separated in individual cages with free access to food (normal Purina Chow pellets) and water during the entire study.

\section{Treadmill Training}

Glucose tolerance tests were performed at $08.00 \mathrm{~h}$ in fed Wistar animals anaesthetised with pentobarbital $(40 \mathrm{mg} / \mathrm{kg}$ body weight IP). A polythene catheter (internal diameter $0.28 \mathrm{~mm}$, external diameter $0.61 \mathrm{~mm}$ ) for blood sampling and the glucose injection was passed into the right atrium through an incision in the right jugular vein. Blood samples $(0.3-0.4 \mathrm{ml})$ were taken via this catheter at zero-time and 5,20 , and $60 \mathrm{~min}$ after the glucose challenge. Following the withdrawal of the blood samples equivalent 
Table 1. Effect of training on body weight, body composition and glycogen content and citrate synthase activity in skeletal muscle of normal rats (number of observations in parentheses)

\begin{tabular}{|c|c|c|c|c|c|c|}
\hline & \multicolumn{2}{|l|}{$\begin{array}{l}\text { Body weight } \\
\text { (g) }\end{array}$} & \multirow{2}{*}{$\begin{array}{l}\text { Relative heart } \\
\text { weight } \\
\text { (mg/kg body mass) }\end{array}$} & \multirow{2}{*}{$\begin{array}{l}\text { Contribution of } \\
\text { skeletal muscle } \\
\text { to the lower } \\
\text { part of the body } \\
(\%)\end{array}$} & \multirow{2}{*}{$\begin{array}{l}\text { Glycogen content } \\
\text { ( } \mu \text { mol glycosyl } \\
\text { units/g wet wt. } \\
\text { muscle) }\end{array}$} & \multirow{2}{*}{$\begin{array}{l}\text { Citrate } \\
\text { synthase in } \\
\mathrm{m} \text {. gastro- } \\
\text { cnemius } \\
\text { ( } \mu \mathrm{mol} / \mathrm{min} / \mathrm{g} \\
\text { wet } \mathrm{wt} \text {.) }\end{array}$} \\
\hline & $\begin{array}{l}\text { at the begin- } \\
\text { ning of }\end{array}$ & $\begin{array}{l}\text { at the } \\
\text { end of } \\
\text { dy }\end{array}$ & & & & \\
\hline \multicolumn{7}{|c|}{$\begin{array}{l}\text { Treadmill training } \\
\text { (10 days) }\end{array}$} \\
\hline controls & $196 \pm 3(8)$ & $212 \pm 4(8)$ & $3.47 \pm 0.06(8)$ & $61 \pm 1(7)$ & - & \\
\hline trained rats & $190 \pm 5(7)$ & $212 \pm 6(7)$ & $3.44 \pm 0.07(7)$ & $62 \pm 1(7)$ & - & \\
\hline \multicolumn{7}{|c|}{$\begin{array}{l}\text { Swim training } \\
\text { (12 days) }\end{array}$} \\
\hline controls & $181 \pm 3(5)$ & $212 \pm 3(5)$ & $3.55 \pm 0.08(8)$ & $63 \pm 1(7)$ & $28.0 \pm 2.9(6)$ & $21.1 \pm 0.6(5)$ \\
\hline trained rats & $186 \pm 1(45)$ & $212 \pm 2(45)$ & $3.57 \pm 0.05(12)$ & $61 \pm 1(6)$ & $32.0 \pm 1.3(6)$ & $22.7 \pm 0.6(5)$ \\
\hline
\end{tabular}

volumes of $0.154 \mathrm{~mol} / \mathrm{l} \mathrm{NaCl}$ containing $50 \mathrm{U}$ heparin/ml were replaced through the catheter. After taking the zero-sample, $1 \mathrm{~g}$ / $\mathrm{kg} \mathrm{D}$-glucose, in a $50 \% \mathrm{w} / \mathrm{v}$ solution was injected over 10 to $20 \mathrm{sec}$ through the catheter which was then flushed with the saline-heparin solution. At the end of the test procedure, the catheter was withdrawn, the jugular vein tied off with cat-gut, the neck wounds closed with silk sutures and the animals randomly divided into an experimental and control group.

Starting three days later, the experimental group was trained in a motor driven circular teadmill for 10 days, with a speed of approximately $12 \mathrm{~m} / \mathrm{min}$. Initial training was 2 times $20 \mathrm{~min}$ on the first day up to 2 times $2 \mathrm{~h}$ daily on the final day. During the entire training period, the rats ran approximately $13 \mathrm{~km}$. All animals were weighed every morning; two rats had to be eliminated from the training group because their weights failed to increase. Forty $h$ after the last treadmill excercise the trained rats and their sedentary controls were subjected to a second intravenous glucose tolerance test as described above, except that this time the cather was inserted via the left jugular vein. Immediately following the test procedure, the animals were killed by exsanguination from the neck and the carcasses were deep frozen for later analyses of body composition.

\section{Swim Training}

Osborne-Mendel rats were divided into a training group and a weight-matched control group. Training consisted of forced swimming in turbulent water at $30-32^{\circ}$ beginning with $20 \mathrm{~min}$ on the first day progressing to 2 times $75 \mathrm{~min}$ on the final day of the training programme which lasted for 2 weeks. Forty h following the last swimming exercise, the rats were subjected to an IV glucose tolerance test which was performed under pentobarbital anaesthesia $(40 \mathrm{mg} / \mathrm{kg}$ body weight IP) beginning at $09.00 \mathrm{h:} 1 \mathrm{~g} /$ $\mathrm{kg}$ body weight $\mathrm{D}$-glucose $(25 \% \mathrm{w} / \mathrm{v}$ solution) was injected into a femoral vein which had been surgically exposed. Wounds were closed with silk sutures; blood samples were taken from the tip of the tail before, and 5,20 and $60 \mathrm{~min}$ following the glucose injection.

In additional experiments, animals were treated identically, and two days after the last swimming exercise the rats were anaesthetised with IP pentobarbital and: a) one gastrocnemius muscle was dissected and rapidly frozen in liquid nitrogen for later analysis of citrate synthase activity; the animals were then killed and the carcasses frozen for later measurement of body composition; or b) skeletal muscle samples from the hindquarter were taken by freeze clamping and transferred into liquid nitrogen for later determination of glycogen levels; or c) subjected to the hindquarter perfusion technique.

\section{Determination of Body Composition}

After recording the total body weight and the weight of the exsanguinated heart, the rat carcasses were cut at the level of the first lumbar vertebral body. The lower part of the carcass, without the tail, was eviscerated and then analysed for various tissue constituents. After removal of the skin and the subcutaneous fat the hindquarter was assayed for interstitial adipose tissue by fat extraction using a Soxhlet apparatus [14]. Thereafter from the remaining tissue, the bones were separated using $5.4 \mathrm{~mol} / \mathrm{l} \mathrm{KOH}$. The muscle content of the lower part of the body was calculated by subtracting the weight of skin and subcutaneous tissue, extractable fat and bones from the total weight of the eviscerated rat hindquarter.

\section{Citrate Synthase Assay}

The activity of citrate synthase (E. C. 4.1.3.7) was determined in homogenates of gastrocnemius muscle. The deep frozen muscles were homogenized and fractionated according to Baldwin et al. [15] and the assay of the enzyme activity was performed at $30^{\circ} \mathrm{C}$ as described by Srere [16]. The coefficient of variation of the citrate synthase assay in different series was between 5 and $6 \%$.

\section{Hindquarter Perfusion}

Details of the perfusion apparatus and the operative procedure of the hindquarter have been described previously $[17,18,19]$. After placing in the perfusion apparatus, the hindquarter was cyclically perfused with $150 \mathrm{ml}$ of the standard medium ( $\mathrm{pH} \mathrm{7.4)} \mathrm{which}$ contained $7.5 \mathrm{mmol} / \mathrm{l}$ glucose, $4 \mathrm{~g}$ bovine albumin $/ 100 \mathrm{ml}$ (Cohn Fraction V, Pentex bovine albumin, Miles Laboratories, Slough, England), $1.5-2.2 \mathrm{mmol} / 1$ lactate, $0.15 \mathrm{mmol} / \mathrm{l}$ pyruvate, washed aged human red cells (ca. $7 \mathrm{~g}$ haemoglobin $/ 100 \mathrm{ml}$ ) and $5 \mu \mathrm{Ci}$ [1 ${ }^{14} \mathrm{C}$-lactate. In some experiments $0.5 \mathrm{mU} / \mathrm{ml}$ insulin (crystalline bovine insulin, Hoechst, Frankfurt, Germany) was added to the perfusate. The flow rate through the preparation was $11 \mathrm{ml} / \mathrm{min}$; the pressure in the tubing leading to the aortic catheter was $8.0-9.5 \mathrm{kPa}(60-70 \mathrm{~mm} \mathrm{Hg})$. The oxygen consumption of the per- 
fused hindquarter, measured as previously described [20], was similar in all experiments at $11.9 \pm 0.5 \mu \mathrm{mol} / 30 \mathrm{~g}$ muscle $\times$ min $(n=34)$. Duplicate samples were taken from the perfusate at zero-time, following a ten min equilibration period, and after a perfusion period of $30 \mathrm{~min}$. Production and utilisation rates were calculated as described previously from changes in the perfusate concentration and expressed in $\mu \mathrm{mol} / 30 \mathrm{~g}$ muscle $\times \min$ [17]. Lactate oxidation was determined on the basis of a quantitative collection of ${ }^{14} \mathrm{CO}_{2}$ produced by the preparation and the lactate specific radioactivity in the perfused muscle according to Berger et al. [19].

\section{Sampling and Processing of Blood, Perfusate and Tissue Specimen}

In the course of the glucose tolerance tests, blood samples were collected in chilled, heparinised plastic tubes, centrifuged and aliquotes of the supernatant were assayed for glucose, or frozen for subsequent insulin determinations. In the hindquarter perfusion experiments, perfusate and tissue specimen (after powdering in liquid $\mathrm{N}_{2}$ ) were deproteinised in ice-cold $0.6 \mathrm{~mol} / 1 \mathrm{HClO}_{4}$. The extracts were neutralised with $\mathrm{KOH}$, and the $\mathrm{KClO}_{4}$ precipitate was removed by centrifugation; the supernatant was frozen for subsequent assay procedures.

\section{Analytical Methods}

Glucose, lactate, alanine, pyruvate, ATP and creatine-phosphate concentrations in perchloric acid extracts were measured using standard enzymatic assays as described previously $[17,18]$. Plasma glucose concentration was determined by the glucose oxidase method [21]. Plasma insulin was measured radioimmunologically using the Pharmacia-kit procedure and reading the results against rat insulin standard solutions as described previously [22]. The variability of the insulin assay at a plasma level of approximately $1.8 \mathrm{ng} / \mathrm{ml}$ was $\pm 8.0 \%$.

\section{Statistical Methods}

Means \pm SEM are given throughout the text in figures and tables. To evaluate the statistical significance of differences between the groups, the unpaired Student's t-test was used unless otherwise indicated.

\section{Results}

\section{In Vivo Experiments}

Neither the treadmill running nor the swimming programmes influenced weight gain, as shown by identical increases in body weights during the study in trained rats and their sedentary controls (Table 1). In contrast, training induced marked changes in the glucose tolerance of the animals: whereas no difference was observed in either plasma glucose and insulin levels following the intravenous administration of $1 \mathrm{~g}$ glucose $/ \mathrm{kg}$ body weight at the beginning and the end of the study period in sedentary control animals (Figure 1), the treadmill training programme was associated with a decrease of plasma glucose con-
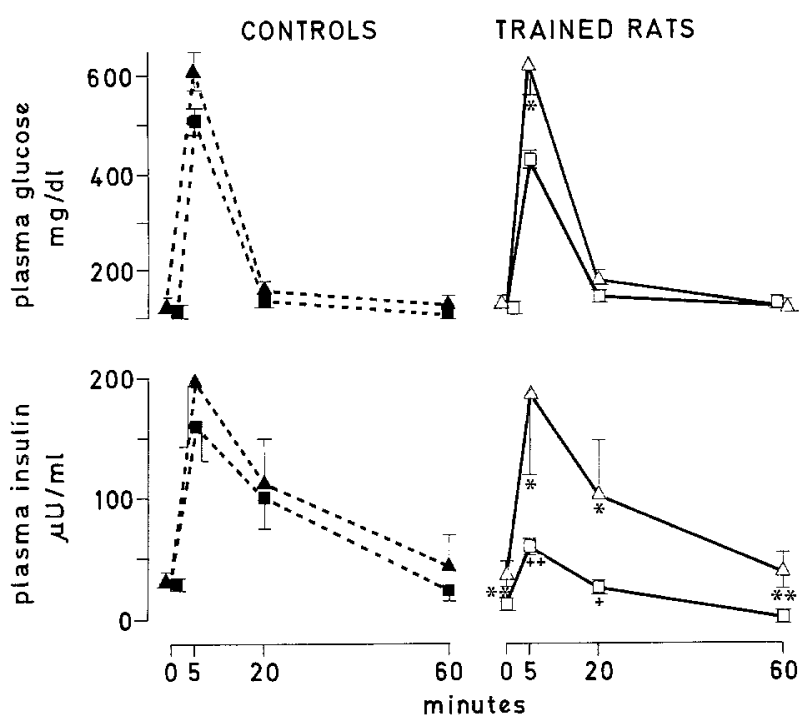

Fig. 1. Effect of treadmill running for 10 days on the intravenous glucose tolerance test $(1 \mathrm{~g} / \mathrm{kg}$ body weight $)$ in fed, normal rats. ---, control rats (non-trained); - , trained rats. $\Delta, \boldsymbol{\Delta}$, glucose tolerance test at the beginning, and $\square, \boldsymbol{\square}$ at the end of the experimental periods. Glucose injections were given at zero time. Statistically significant difference between first and second glucose tolerance test in trained rats (paired comparison) at $\mathrm{p}<0.05\left({ }^{*}\right)$ and $\mathrm{p}<$ $0.025\left(^{* *}\right)$. Statistically significant difference between the second glucose tolerance tests in the trained and the control group (unpaired comparison) at $\mathrm{p}<0.05(+)$ and $\mathrm{p}<0.025(++)$

centrations at $5 \mathrm{~min}$ after the glucose challenge and significantly lower plasma insulin levels at all time points measured (Figure 1).

It is of note that in the control group, the glucose tolerance test curves both for glucose and insulin remained indistinguishable on repetition after two weeks, whereas the training-induced alterations in plasma insulin levels were equally apparent on comparison with the glucose tolerance test of the same group of animals at the onset of the study or when compared with the respective data seen in the control group at the end of the study (Figure 1). For this reason, the initial glucose tolerance tests were abandoned in the swim training programme in order to minimise the danger of wound infections. On comparing the results of the glucose tolerance tests in the trained and untrained control animals, substantial effects of the training procedure were found. Plasma glucose and insulin levels were significantly lower in the trained animals both pre-glucose and at all times during the glucose tolerance test (Figure 2).

\section{In Vitro Experiments: [1] Perfused Hindquarter}

In order to investigate the insulin sensitivity of the skeletal muscle mass, the isolated hindquarters of 

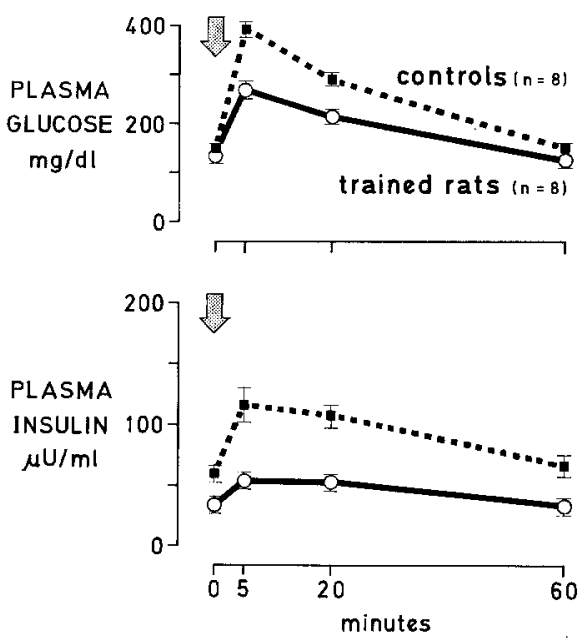

Fig. 2. Effect of swim training for 14 days on the intravenous glucose tolerance test $(1 \mathrm{~g} / \mathrm{kg}$ body weight) in normal, fed rats. The arrow indicates the glucose injection. Plasma glucose and insulin levels are significantly different between the trained animals and the control group at all time points $(p<0.05)$. ---, controls; trained rats

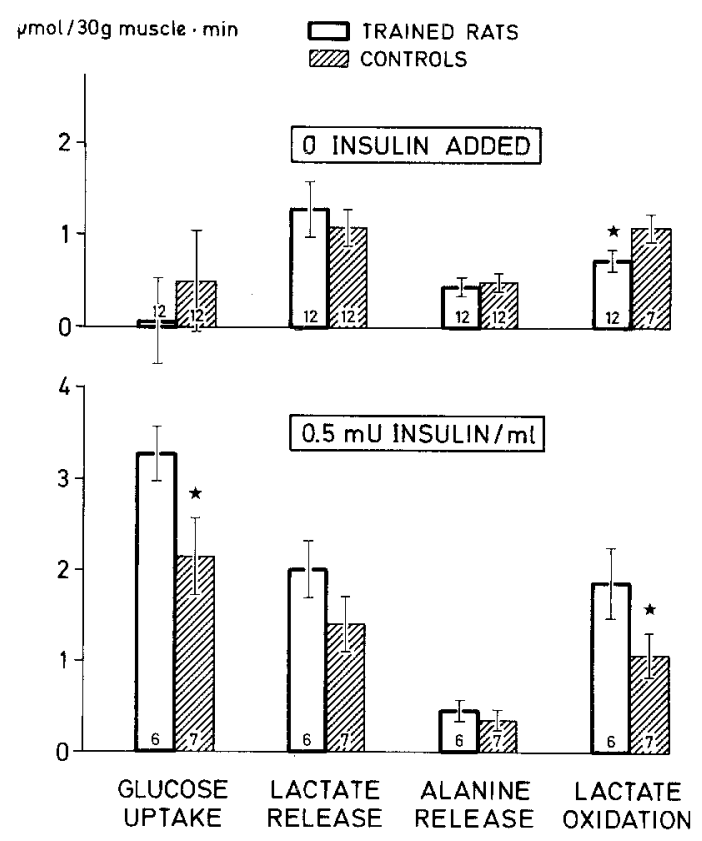

Fig. 3. Effect of swim training on glucose metabolism of the isolated perfused hindquarter of normal rats. * indicates significant differences between the groups at $p<0.05$. The number of observations are indicated at the bottom of the columns

Table 2. Effect of swim training on tissue metabolites in skeletal muscle at the end of the hindquarter perfusion in normal rats (number of observations in parentheses)

\begin{tabular}{|c|c|c|c|c|}
\hline Insulin & $\begin{array}{l}\text { Controls } \\
0\end{array}$ & $\begin{array}{l}\text { Swim-trained rats } \\
0\end{array}$ & $\begin{array}{l}\text { Controls } \\
0.5 \mathrm{mU} / \mathrm{ml}\end{array}$ & $\begin{array}{l}\text { Swim-trained rats } \\
0.5 \mathrm{mU} / \mathrm{ml}\end{array}$ \\
\hline Lactate & $1.27 \pm 0.18(12)$ & $1.37 \pm 0.07(10)$ & $1.07 \pm 0.22(7)$ & $1.35 \pm 0.18(6)$ \\
\hline Pyruvate & $0.14 \pm 0.02(12)$ & $0.12 \pm 0.02(10)$ & $0.08 \pm 0.03(7)$ & $0.07 \pm 0.01(6)$ \\
\hline ATP & $5.58 \pm 0.30(12)$ & $5.07 \pm 0.35(10)$ & $5.12 \pm 0.14(7)$ & $5.95 \pm 0.40(6)$ \\
\hline Creatine-P & $18.8 \pm 0.9 \quad(12)$ & $17.4 \pm 1.2(10)$ & $18.4 \pm 0.9$ & $19.2 \pm 1.2$ \\
\hline
\end{tabular}

animals that had been subjected to the swimming programme and their sedentary controls were perfused. In the absence of added insulin, lactate oxidation rates were significantly decreased in trained animals, whereas glucose uptake, lactate and alanine release showed no differences between the two experimental groups (Figure 3). When $0.5 \mathrm{mU} / \mathrm{ml}$ insulin were added to the perfusate, a dose which, under these experimental conditions, elicits a submaximal effect on various indices of skeletal muscle glucose metabolism [23], both values for glucose uptake and lactate oxidation of the perfused muscles were significantly higher in the trained animals indicating increased insulin sensitivity (Figure 3 ). Both in the absence and in the presence of added insulin, metabolite levels in the skeletal muscle mass at the end of the perfusion such as lactate, pyruvate, ATP, creatine-phosphate and glycogen were unaffected by the training procedure (Table 2).
In Vitro Experiments:

[2] Body Composition Analyses

No differences were found at the end of the experimental period in the relative heart weight and the contribution of skeletal muscle to the lower half of the body between trained and control animals (Table 1). In addition, skeletal muscle glycogen levels and the activity of citrate synthase in the gastrocnemius muscle remained unaffected by the swimming programme (Table 1).

\section{Discussion}

The results of this study document increased capacity for glucose disposal in vivo following physical training: in normal rats, glucose tolerance could be markedly improved by swim training and, albeit to a les- 
ser extent, by a treadmill training programme. This effect was associated with a decrease in basal and glucose-stimulated insulinaemia. As shown by Björntorp et al. $[9,10,11,12]$ in humans, these findings indicate a training-induced improvement of tissue insulin sensitivity. In the swim training study such an increased sensitivity towards insulin was demonstrated with respect to skeletal muscle glucose metabolism. Since the skeletal muscle mass in the rat is an important site of disposal of an intravenous glucose load [24], this observation might, at least in part, be the basis for the increase in the insulin sensitivity and the improvement of glucose tolerance seen as a result of physical training.

The mechanism for this training-induced facilitation of insulin-dependent glucose disposal remains to be investigated. Since the training programme involved in this study was of short duration and mild intensity, as demonstrated by the lack of alterations in body composition, an increase in the relative contribution of insulin-sensitive tissues, such as skeletal muscle, could be ruled out. Likewise, any traininginduced major changes in the oxidative capacity of the skeletal muscle mass [25] were excluded by demonstrating unaltered citrate synthase activities in the gastrocnemius muscles. However, the characteristic shift in fuel metabolism induced by training was nevertheless evident, i. e. decreased basal carbohydrate oxidation (Figure 3), and thus the preference of muscle to oxidise fat $[26,27,28]$. In addition, alterations in food intake which might have altered the carbohydrate metabolism of the trained rats could at best be minimal since the weight gain in the trained rats was unaltered and the body composition found to be identical between trained and untrained animals. On the other hand, the training-induced increases in glucose tolerance cannot be attributed to the well described $[29,30]$ post-exercise increase in peripheral glucose disposal due to decreased glycogen depots, since the glucose tolerance test and the last exercise period were $40 \mathrm{~h}$ apart and skeletal muscle glycogen levels showed no differences between trained rats and their resting controls (Table 1).

Thus, it seems reasonable to consider that the increase in insulin sensitivity of skeletal muscle glucose metabolism might be due to a short-term increase of the number and/or affinity of the insulin receptors. Such an increase of specific insulin-binding to lymphocytes has recently been reported following prolonged exercise in man [31]. Earlier observations reported by Holm [32] have indicated that chronic tissue hypoxia distal of an arterio-sclerotic stenosis in man is associated with increased glucose metabolism of skeletal muscle. Subsequent studies have revealed identical findings in skeletal muscles of rats which had been subjected to intermittent hypoxia by decreasing the environmental oxygen for several hours daily [32]. Thus, it appears conceivable that the improvement of glucose tolerance and insulin-sensitivity shown in this study might be mediated by the repeated periods of tissue hypoxia during the training procedure. The more profound effect of the swim training when compared with the treadmill running might be due to a higher degree of hypoxia during swimming. This would be compatible with the findings of Gould and Rawlinson [33] showing that sugar uptake of most leg muscles was stimulated more vigorously by swimming than by running.

At present, definite data on the effect of training on the impaired glucose tolerance of diabetic patients are not available. If the findings of this study made in rats were applicable to diabetic man, physical training might prove to be a rational form of treatment, especially for patients with relative insulin deficiency and insulin resistance such as is often seen in maturity-onset type diabetics.

Acknowledgements. This work has been supported by the Deutsche Forschungsgemeinschaft, SFB 113, Diabetes-Forschung Düsseldorf (G-2, Berger; and C 1, C 2 Herberg), the Swiss National Science Foundation, grant No.3.774 - 076 SR, and Landesamt für Forschung des Landes Nordrhein-Westfalen.

The authors thank Dr. F. A. Gries for reviewing the manuscript. The expert technical assistance of Ms. Schäfer, Major, Reinhold, Schnickman, Kreutzer, Thiemann is gratefully acknowledged.

\section{References}

1. Joslin, E. P.: The treatment of diabetes mellitus. In: Treatment of diabetes mellitus, 10th edition. Joslin, E. P., Root, H. F., White, P., Marble, A. (Eds.), pp. 243-300. Philadelphia: Lea and Febiger 1959

2. Berger, M., Berchtold, P., Gries, F. A., Zimmermann, H.: Die Bedeutung von Muskelarbeit und -training für die Therapie des Diabetes Mellitus. Dtsch. Med. Wochenschr. 103, 439-443 (1978)

3. Berger, M., Berchtold, P., Cüppers, H. J., Drost, H., Kley, H. K., Müller, W. A., Wiegelmann, W., Zimmermann-Telschow, H., Gries, F. A., Krüskemper, H. L., Zimmermann, H.: Metabolic and hormonal effects of muscular exercise in juvenile type diabetics. Diabetologia 13, 355-365 (1977)

4. Blotner, $\mathrm{H}$.: Effect of prolonged physical inactivity on tolerance of sugar. Arch. Intern. Med. 75, 39-44 (1945)

5. Lipman, R. L., Raskin, P., Love, T., Triebwasser, J., Lecocq, F. R., Schnure, J. J.: Glucose intolerance during decreased physical activity in man. Diabetes 21, 101-107 (1972)

6. Mann, G. V., Garett, H. L., Farhi, A., Murray, H., Billings, F. T., Shute, E., Schwarten, S. E.: Exercise to prevent coronary heart disease. Am. J. Med. 46, 12-27 (1969)

7. Montoye, H. J., Block, W. D., Metzner, H., Keller, J. B.: Habitual physical activity and glucose tolerance. Diabetes $\mathbf{2 6}$, 172-176 (1977)

8. Hirsch, E. Z., Hellerstein, H. K., McLeod, A. A.: Physical training and coronary heart disease. In: Exercise and the heart, pp. 106-187. Springfield, Ill.: C. C. Thomas 1972 
9. Björntorp, P., de Jounge, K., Sjöstrom, L., Sullivan, L.: The effect of physical training on insulin production in obesity. Metabolism 19, 631-637 (1970)

10. Björntorp, P., Berchtold, P., Grimby, G., Lindholm, B., Sanne, H., Tibblin, G., Wilhelmsen, L.: Effects of physical training on glucose tolerance, plasma insulin and lipids and on body composition in men after myocardial infarction. Acta Med. Scand. 192, 439-443 (1972)

11. Björntorp, P., de Jounge, K., Sjöström, L., Sullivan, L.: Physical training in human obesity. II. Effects on plasma insulin in glucose intolerant subjects without marked hyperinsulinemia. Scand. J. Clin. Lab. Invest. 32, 42-45 (1973)

12. Björntorp, P., Holm, G., Jacobsson, B., Schiller-de Jounge, K., Lundberg, P.-A., Sjöström, L., Smith, U., Sullivan, L.: Physical training in human hyperplastic obesity. IV. Effects on the hormonal status. Metabolism 26, 319-328 (1977)

13. Lohmann, D., Liebold, F., Heilmann, W., Senger, H., Pohl, A.: Diminished insulin response in highly trained athletes. Metabolism 27, 521-542 (1978)

14. Vogel, A. I.: Practical organic chemistry, 3rd Edition, pp. 153-154. London: Longmans, Green and Co. 1961

15. Baldwin, K.M., Klinkerfuss, G. H., Terjung, R. L., Mole, P. A., Holloszy, J. O.: Respiratory capacity of white, red, and intermediate muscle: adaptive response to exercise. Am. J. Physiol. 222, 333-378 (1972)

16. Srere, P. A.: Citrate synthase. Methods Enzymol. 13, 3-5 (1969)

17. Ruderman, N. B., Houghton, C. R. S., Hems, R.: Evaluation of the isolated perfused rat hindquarter for the study of muscle metabolism. Biochem. J. 124, 639-651 (1971)

18. Berger, M., Hagg, S. A., Ruderman, N. B.: Glucose metabolism in perfused skeletal muscle. Interaction of insulin and exercise on glucose uptake. Biochem. J. 146, 231-238 (1975)

19. Berger, M., Hagg, S. A., Goodman, M. N., Ruderman, N. B. Glucose metabolism in perfused skeletal muscle. Effects of starvation, diabetes, fatty acids, acetoacetate, insulin and exercise on glucose uptake and disposition. Biochem. J. 158, 191-202 (1976)

20. Kemmer, F. W., Berger, M., Herberg, L., Gries, F. A.: Effects of metformin on glucose metabolism of isolated perfused rat skeletal muscle. Drug Res. 27, 1573-1576 (1977)

21. Bergmeyer, H. U., Bernt, E.: D-Glucose Bestimmung mit Glukose-Oxydase und Reoxydase. In: Methoden der enzymatischen Analyse. Bergmeyer, H. U. (Ed.), pp. 1172-1176. Weinheim/Bergstraße, West Germany: Verlag Chemie 1970

22. Herberg, L., Kley, H. K.: Adrenal function and the effect of a high fat diet on C57B1/6J and C57B1/6J-ob/ob mice. Horm. Metab. Res. 7, 410-415 (1975)

23. Kemmer, F. W., Berger, M., Herberg, L., Gries, F. A., Wierdeyer, L., Becker, K.: Glucose metabolism in the fatty Zucker rat. Biochem. J. (in press)

24. Curtis-Prior, P. B., Tretheway, J., Stewart, G. A., Hanley, T.: The contribution of different organs and tissues of the rat to assimilation of glucose. Diabetologia 5, 384-391 (1969)

25. Holloszy, J. O., Booth, F.W.: Biochemical adaptations to endurance exercise in muscle. Annu. Rev. Physiol. 38, 273-291 (1976)

26. Fitts, R. H., Booth, F. W., Winder, W. W., Holloszy, J. O.: Skeletal muscle respiratory capacity, endurance, and glycogen utilization. Am. J. Physiol. 228, 1029-1033 (1975)

27. Karlsson, J., Nordesjö, L.-O., Saltin, B.: Muscle glycogen utilisation during exercise after physical training. Acta Physiol. Scand. 90, 210-217 (1974)

28. Saltin, B., Karlsson, J.: Muscle glycogen utilization during work of different intensities. In: Muscle metabolism during exercise. Pernow, B., Saltin, B. (Eds.), pp. 289-299. New York: Plenum Press 1971

29. Roch-Norlund, A. E.: Muscle glycogen synthetase in diabetic man. Acta Physiol. Scand. [Suppl.] 358, 1-27 (1972)

30. Pruett, E. D. R.: Fat and carbohydrate metabolism in exercise and recovery, and its dependence upon work load severity. Academic Dissertation, Institute of Work Physiology, University of Oslo 1971

31. Soman, V., Koivisto, V., Grantham, P., Felig, P.: Increased insulin binding to monocytes after exercise: cellular mechanism of augmented insulin sensitivity. Diabetes 27 [Suppl. 1], 449 (1978)

32. Holm, J.S. E.: Skeletal muscle metabolism in patients with peripheral arterial insufficiency. Academic Dissertation, Göteborg 1972

33. Gould, M. K., Rawlinson, W. A.: Effect of natural exercise on pentose transport in rat skeletal muscle. Am. J. Physiol. 211, $147-150(1966)$

Received: July 10,1978

and in revised form: September 19, 1978

Prof. Dr. Michael Berger

Medizinische Universitätsklinik E

Moorenstraße 5

D-4000 Düsseldorf

Federal Republic of Germany 